\title{
A Novel Electrochemical Aptamer Biosensor Based on DNAzyme Decorated Au@Ag Core-Shell Nanoparticles for $\mathbf{H g}^{2+}$ Determination
}

\author{
Yanling Zhao and Xianmei Xie* \\ College of Chemistry and Chemical Engineering, Taiyuan University of Technology, \\ 030024 Taiyuan, P.R. China
}

\begin{abstract}
As a kind of important water pollutant, heavy metal ions have a detrimental effect on the health of human. In this study, Au@ Ag core-shell nanoparticles were synthesized by simple reduction of $\mathrm{Ag}^{+}$around $\mathrm{Au}$ nanoparticles and functionalized by DNAzyme. Based on thymine- $\mathrm{Hg}^{2+}$-thymine binding mode, a sensitive aptamer biosensor was constructed by utilizing functionalized Au@Ag core-shell nanoparticles as labels, and the sensitivity was enhanced by DNAzyme due to the catalysis toward $\mathrm{H}_{2} \mathrm{O}_{2}$. Under optimal conditions, square wave voltammetry was carried out to measure the current derived from $\mathrm{Au} @ \mathrm{Ag}$ nanoparticles labels. The current response of biosensor increased with the increasing of $\mathrm{Hg}^{2+}$ concentration, which presented linear relation in the range of $0.002-20 \mu \mathrm{g} \mathrm{L}{ }^{-1}$ with limit of detection of $0.006 \mu \mathrm{g} \mathrm{L}^{-1}$. Meanwhile, the electrochemical biosensor showed superior reversibility, stability, repeatability, and selectivity.
\end{abstract}

Keywords: $\mathrm{Hg}^{2+}$, electrochemical biosensor, T- $\mathrm{Hg}^{2+}-\mathrm{T}, \mathrm{Au} @ \mathrm{Ag}$, DNAzyme

\section{Introduction}

Water pollutions including pathogens contaminants, toxic pollutant, inorganic pollutant and so on, exert a detrimental influence on people's health. ${ }^{1,2}$ Therein, heavy metal ion is one non-negligible water pollutant. Mercury is easy to be absorbed by skin, respiratory and digestive tract, and to be accumulated in the body, which could damage the structure of protein and take a toll on kidney and liver. ${ }^{3,4}$ To monitor the concentration of $\mathrm{Hg}^{2+}$, diverse analytical methods are developed, such as fluorescent, ${ }^{5}$ surface-enhanced Raman scattering (SERS), ${ }^{6}$ colorimetric, ${ }^{7}$ inductively coupled plasma mass spectrometry (ICP-MS) ${ }^{8}$ and electrochemical ones. ${ }^{9}$ Although each method has its merits, some complex operations and expensive instruments are required. Among them, electrochemical assay has attracted more and more attention due to its low-cost, high sensitivity and feasibility.

Oligonucleotides have drawn considerable interest for constructing electrochemical biosensor. Aptamers are short DNA or RNA molecules, which have a wide range of applications in detection of DNA, RNA, ATP and so on, because of its outstanding efficiency and selectivity. ${ }^{10-13}$ Excitingly, the aptamer sensors could detect not only biological molecules, but also metal ions

*e-mail: xiexianmei@tyut.edu.cn including $\mathrm{Ag}^{+}, \mathrm{Hg}^{2+}, \mathrm{Pb}^{2+}, \mathrm{Mg}^{2+}$, and $\mathrm{Zn}^{2+} .{ }^{14-17}$ For example, Cui et al. ${ }^{18}$ presented an efficient electrochemical sensor for $\mathrm{Pb}^{2+}$ detection using functionalized iron-porphyrinic metal-organic framework as probe. Meanwhile, a variety of aptamer biosensors have been fabricated based on the chelation between $\mathrm{Hg}^{2+}$ and thymine (T) ${ }^{19,20}$ For example, Wei et al. ${ }^{21}$ designed thymine-functionalized silver nanoparticle $(\mathrm{Ag}-\mathrm{T})$ as the sensing unit for $\mathrm{Hg}^{2+}$ determination and assembled individual sensing units for signal amplification. Significant progress has been made in the field of $\mathrm{Hg}^{2+}$ determination, however, increasing sensitivity and decreasing detection limit are always the goals of scientists.

The unique features of nanomaterials have opened up extensive ways for enhancing the sensitivity of electrochemical aptamer biosensor. A range of inorganic, organic and hybrid nanomaterials have been widely applied. ${ }^{22-25}$ Among them, noble metal nanomaterials exhibit relevant characteristics due to inherent catalysis action. Especially, bimetallic nanoparticles have shown better catalytic activity than the monometallic ones with the same elements. ${ }^{26-28}$ For example, Wang et al..$^{29}$ synthesized bimetallic $\mathrm{AuCu}$ nanowires (AuCuNWs) via a facile water solution method and the enhancing electrocatalytic activity toward the oxidation of $\mathrm{H}_{2} \mathrm{O}_{2}$ was observed. DNAzymes with the character of biological enzymes are particularly appealing because they are easily synthesized and applied in 
catalytic signal amplification. Hemin/G-quadruplex as one kind of DNAzyme possessing peroxidase activity has been widely applied in detecting targets from proteins and DNAs, to small molecules or metal ions. For example, Wang et al..$^{30}$ constructed a novel biosensor based on G-quadruplexhemin DNAzyme to detect activity of S1 nuclease.

In this study, Au@Ag core-shell nanoparticles were synthesized by simple reduction of $\mathrm{AgNO}_{3}$ onto the surface of Au NPs. Further, Au@Ag nanoparticles were modified by DNAzyme, which was employed as labels to construct electrochemical aptamer biosensor for $\mathrm{Hg}^{2+}$ detection. By introducing DNAzyme, the sensitivity of sensor was enhanced and trace of $\mathrm{Hg}^{2+}$ was determined by pulse voltammetric techniques.

\section{Experimental}

\section{Chemicals and reagents}

Oligonucleotide designed in this experiment was synthesized by Sangon Biotech. Co., Ltd. (Shanghai, China), which was purified by high-performance liquid chromatography and confirmed by mass spectrometry. The sequences of aptamer are listed as follows:

DNA1: 5'-SH- $\left(\mathrm{CH}_{2}\right)_{6}$-AAA ATT TTG CTT TGG TTT-3'
DNA2: 5'-SH-( $\left(\mathrm{CH}_{2}\right)_{6}$-AAA AAT TTC CTT TGC TTT-3'
DNA3: 5'-SH- $\left(\mathrm{CH}_{2}\right)_{6}$-GGG TAG GGC GGG TTG GGT-3'

Chloroauric acid $\left(\mathrm{HAuCl}_{4} \cdot 4 \mathrm{H}_{2} \mathrm{O}\right)$, trisodium citrate $\left(\mathrm{C}_{6} \mathrm{H}_{5} \mathrm{Na}_{3} \mathrm{O}_{7} \cdot 2 \mathrm{H}_{2} \mathrm{O}\right)$, ascorbic acid (AA), silver nitrate $\left(\mathrm{AgNO}_{3}\right)$, mercuric chloride $\left(\mathrm{HgCl}_{2}\right)$, polyvinylpyrrolidone (PVP), 6-mercapto-1-hexanol (MCH), L-cysteine and hemin were purchased from Aladdin Reagent Company (Shanghai, China). All the other chemicals were of analytical reagents grade and used without further purification. The $0.2 \mathrm{M}$ phosphate buffer solutions (PBS) at various $\mathrm{pH}$ values were prepared by mixing the stock solutions of $0.2 \mathrm{M} \mathrm{NaH}_{2} \mathrm{PO}_{4}, 0.2 \mathrm{M} \mathrm{Na}_{2} \mathrm{HPO}_{4}$ and $0.2 \mathrm{M}$ $\mathrm{KCl}$ in different proportions.

\section{Preparation of Au@Ag nanoparticles}

Firstly, Au nanoparticles were synthesized according to our previous report. ${ }^{31}$ Briefly, $1 \mathrm{~mL} \mathrm{HAuCl}{ }_{4}(1 \%$, wt. \%) was added into $100 \mathrm{~mL}$ of double-distilled water, and heated to boiling. Then $2.5 \mathrm{~mL}$ of $\mathrm{C}_{6} \mathrm{H}_{5} \mathrm{Na}_{3} \mathrm{O}_{7} \cdot 2 \mathrm{H}_{2} \mathrm{O}(1 \%$, wt.\%) was added, heated continually, and the color of solution changed from drab yellow into dark red. The reaction proceeded for $15 \mathrm{~min}$ and the solution was cooled down to room temperature. Secondly, $0.65 \mathrm{~mL}$ of PVP (1\%, wt.\%) was added into $8 \mathrm{~mL}$ suspension solution containing Au NPs and stirred $5 \mathrm{~min}$, following that $120 \mu \mathrm{LAA}(100 \mathrm{mM})$ was added into the mixed solution, meanwhile, $\mathrm{pH}$ of the solution was adjusted to 8.5 by $\mathrm{NaOH}$. After, $85 \mu \mathrm{L}$ of $\mathrm{AgNO}_{3}$ solution $(100 \mathrm{mM})$ was dropwise added into the above solution under strong stirring. Finally, the Au@Ag nanoparticles were collected by centrifugation, washed at least three times and stored into PBS (pH 7.0) at $4{ }^{\circ} \mathrm{C}$ when not in use.

Decoration of $\mathrm{Au} @ \mathrm{Ag}$ nanoparticles with DNA2 and DNAzyme (DNA2-Au@Ag-DNAzyme)

To fully collect synthesized DNA2 and DNA3, DNA firstly was centrifuged at $14,000 \mathrm{rpm}$ for $10 \mathrm{~min}$. $250 \mu \mathrm{L}$ of DNA2 $(1 \mathrm{mM})$ and $250 \mu \mathrm{L}$ of DNA3 $(1 \mathrm{mM})$ were added into $1 \mathrm{~mL}$ of prepared $\mathrm{Au} @ \mathrm{Ag}$ solution and shaked for $5 \mathrm{~min}$ at room temperature. To completely combine DNA with Au@Ag, the solution was transferred into refrigerator $\left(4^{\circ} \mathrm{C}\right)$ to keep the activity of DNA for further reaction for $5 \mathrm{~h}$. Then the mixed solution was centrifuged and washed to remove redundant DNA. DNA2-Au@Ag-DNA3 conjugation was collected. Following that $500 \mu \mathrm{L}$ of hemin $(0.2 \mathrm{mM})$ was added into the DNA2-Au@Ag-DNA3 solution and Hemin/G-quadruqlex generated which was used as a kind of DNAzyme. After centrifugation, DNA2-Au@Ag-DNAzyme conjugate was collected, redispersed into PBS solution (pH 7.0) and stored at $4{ }^{\circ} \mathrm{C}$.

\section{Fabrication of DNA1 modified gold electrode}

An Au electrode ( $2 \mathrm{~mm}$ in diameter) was polished repeatedly with 1.0 and $0.3 \mu \mathrm{m}$ alumina slurry, followed by successive sonication in distilled water, acetone and ethanol for $5 \mathrm{~min}$, and dried in air. Then the electrode was continuously scanned in a freshly prepared deoxygenated $\mathrm{H}_{2} \mathrm{SO}_{4}$ solution $(0.5 \mathrm{M})$ with the potential range of -0.3 to $1.5 \mathrm{~V}$ until a stable voltammogram characteristic of the cleaned gold electrode was established. After washing with double-distilled water, the cleaned Au electrode was immersed in the DNA1 solution $(1.0 \mathrm{mM})$ and reacted for $5 \mathrm{~h}$ (designed as DNA1/Au). Then the electrode was immersed into the solution of $\mathrm{MCH}(1.0 \mathrm{mM})$ to eliminate the nonspecific adsorption sites at the surface of $\mathrm{Au}$ electrode. Subsequently, the prepared DNA1/Au was stored in the refrigerator when not in use.

\section{Electrochemical measurements toward $\mathrm{Hg}^{2+}$}

With the goal of measuring $\mathrm{Hg}^{2+}$, two-step incubation method was employed, which was beneficial to the bound 
of $\mathrm{T}-\mathrm{Hg}^{2+}-\mathrm{T} .^{32}$ First, the prepared DNA1/Au electrode was incubated with various concentrations of $\mathrm{Hg}^{2+}$ for $35 \mathrm{~min}$ at room temperature (designed as $\mathrm{Hg}^{2+} / \mathrm{DNA} 1 /$ $\mathrm{Au})$. Following that, the $\mathrm{Hg}^{2+} / \mathrm{DNA} 1 / \mathrm{Au}$ electrode was immersed into DNA2-Au@Ag-DNAzyme solution for another $35 \mathrm{~min}$, and the double-strand DNA structure was formed based on T- $\mathrm{Hg}^{2+}-\mathrm{T}$ (designed as DNA2-Au@ AgDNAzyme $\left./ \mathrm{Hg}^{2+} / \mathrm{DNA} 1 / \mathrm{Au}\right)$. After the test, the prepared biosensor was immersed into L-cysteine solution $(1.0 \mathrm{mM})$ to remove $\mathrm{Hg}^{2+}$ by the bonding between $\mathrm{Hg}^{2+}$ and L-cysteine and the electrode of DNA1/Au was renewed. Scheme 1B shows the fabrication process of electrochemical aptamer biosensor and electrochemical measurement principle for $\mathrm{Hg}^{2+}$ detection. All electrochemical measurements were carried out on CHI 660E (Chenhua, Shanghai, China) by three-electrode system with saturated calomel electrode (SCE) as reference electrode, Pt wire as counter electrode, and modified Au electrode as working electrode. Square wave voltammetry (SWV) was employed to characterize the behavior of biosensor from the range of $0-0.3 \mathrm{~V}$ (parameters: potential step, $4 \mathrm{mV}$; frequency, $25 \mathrm{~Hz}$; amplitude, $25 \mathrm{mV}$ ) in PBS buffer solution (pH 6.5). Each measurement was repeated three times at room temperature.
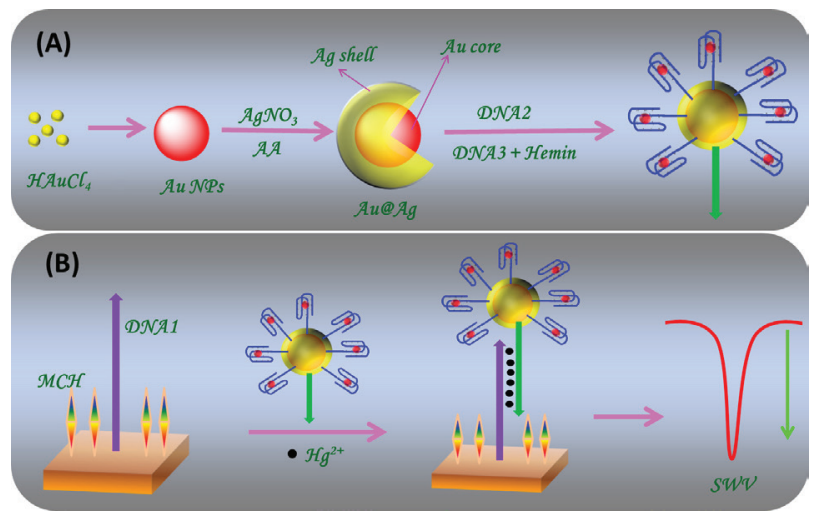

Scheme 1. (A) The building-up process of the conjugates of DNA2-Au@ Ag-DNAzyme; and (B) the fabrication process of the electrochemical aptamer biosensor and measurement principle.

\section{Results and Discussion}

\section{Characterizations of $\mathrm{Au} @ \mathrm{Ag}$ nanoparticles}

Au@Ag core-shell bimetallic nanoparticles were synthesized under the protection of surfactant by reducing $\mathrm{Ag}^{+}$to $\mathrm{Ag}^{0}$, which was deposited onto the surface of $\mathrm{Au}$ NPs. First, $\mathrm{Au}^{3+}$ was reduced to $\mathrm{Au}^{0}$ by trisodium citrate and the morphology of Au NPs was characterized by transmission electron microscopy (TEM). As seen from Figure $1 \mathrm{~A}$, the $\mathrm{Au}$ nanoparticles were spherical with uniform distribution concentrating on the size of $16 \mathrm{~nm}$.
And there are a great deal of carboxyl on the surface of $\mathrm{Au}$ NPs due to the participation of trisodium citrate, which could absorb electropositive $\mathrm{Ag}^{+}$based on the electrostatic interaction. Hence, Ag shell could occur under the reducing action. Figure 1B showed that Au@Ag nanoparticles performed with shell-core structure. The fact was that
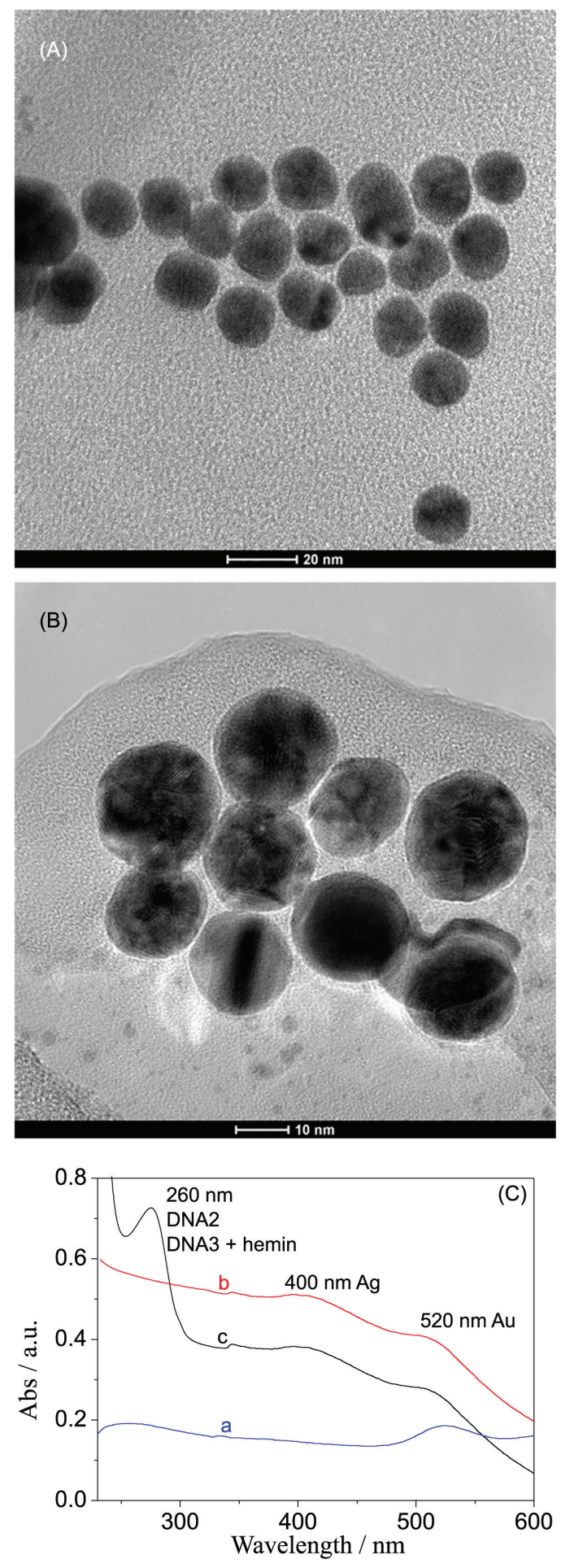

Figure 1. TEM images of (A) Au and (B) Au@ Ag; (C) UV-Vis spectra of (a) Au, (b) Au@Ag, and (c) DNA2-Au@Ag-DNAzyme. 
the core of $\mathrm{Au}$ was about $16 \mathrm{~nm}$ and the shell of Ag was about $2 \mathrm{~nm}$.

Further, UV-Vis absorption spectrum was utilized to trace the formation process of DNA2-Au@Ag-DNAzyme, which was visually shown in Scheme 1A. It could be seen from Figure $1 \mathrm{C}$ that the characteristic absorption peak at $520 \mathrm{~nm}$ attributed to Au NPs was observed in the solution containing Au NPs, Au@Ag NPs, and DNA2-Au@Ag-DNAzyme conjugate (curves a-c). In addition, the characteristic absorption peak at $400 \mathrm{~nm}$ assigned to Ag NPs was obtained in the solutionwithAu@AgNPsandDNA2-Au@Ag-DNAzyme conjugate (curves b and c), moreover, the absorption peak at $260 \mathrm{~nm}$ resulted from DNA also could be acquired in the solution of DNA2-Au@Ag-DNAzyme conjugate (curve c). The results indicated that the DNA2-Au@Ag-DNAzyme conjugate had been successfully synthesized.

\section{Electrochemical study of DNA2-Au@Ag-DNAzyme conjugation}

The electrochemical signal of aptamer biosensor was derived from DNA2-Au@Ag-DNAzyme conjugation. The electrochemical feature of this conjugate is of great importance. $5 \mu \mathrm{L}$ of DNA2-Au@Ag-DNAzyme conjugations solution were casted on the surface of $\mathrm{Au}$ electrode (designed as DNA2-Au@Ag-DNAzyme/Au), then SWV was carried out in the range of $0-0.3 \mathrm{~V}$ in the PBS (pH 6.5). Figure 2A displayed an obvious reduction peak at $156 \mathrm{mV}$ (curve b) compared to bare Au electrode (curve a) resulted from Ag NPs of conjugates. Meanwhile, the reduction peak further was enhanced $(\Delta \mathrm{I}=3.64 \mu \mathrm{A}$, where $\mathrm{I}$ is the current) when $0.25 \mathrm{mM} \mathrm{H}_{2} \mathrm{O}_{2}$ was added into PBS buffer solution (curve c) due to the catalysis of DNAzyme toward $\mathrm{H}_{2} \mathrm{O}_{2}$, which was beneficial to increase the sensitivity of the biosensor. Figure 2B displayed cyclic voltammetry $(\mathrm{CV})$ curves at different scan rates $\left(10,20,40,60,80,100,120,140,160,190,200 \mathrm{mV} \mathrm{s}^{-1}\right)$.

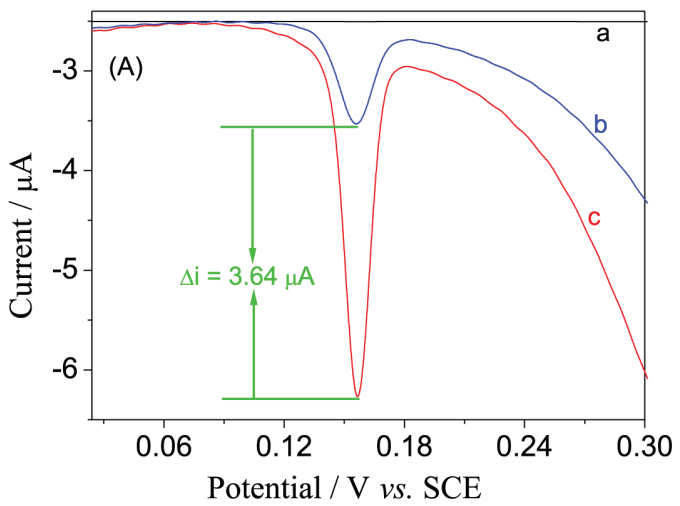

The result suggested that the electrochemical reaction of DNA2-Au@Ag-DNAzyme modified Au electrode was a diffusion-controlled process due to the linear relationship between $I$ and $v^{1 / 2}$, which was in accordance with the Randles-Sevcik equation.

Comparison of current responses of $\mathrm{Hg}^{2+}$ biosensor based different signal tags

In order to highlight the advantages of DNA2-Au@Ag-DNAzyme conjugation, another label-DNA2-Au@Ag was prepared with similar steps. Two kinds of aptamer biosensors for $\mathrm{Hg}^{2+}$ detection were constructed based on those different signal tags at the same conditions (designed as DNA2-Au@Ag-DNAzyme/ $\mathrm{Hg}^{2+} / \mathrm{DNA} 1 / \mathrm{Au}$ and DNA2-Au@Ag/ $\left.\mathrm{Hg}^{2+} / \mathrm{DNA} 1 / \mathrm{Au}\right)$. Initially, electrochemical impedance spectroscopy (EIS) was carried out to characterize the assembling process of aptamer biosensor. As shown in Figure 3A, the semicircular diameter of DNA1/Au (curve b) was larger than bared Au electrode (curve a) due to the inhibition effect of DNA on electron transfer; further, the EIS of DNA2-Au@Ag-DNAzyme/Hg ${ }^{2+} / \mathrm{DNA} 1 / \mathrm{Au}$ (curve c) increased because of the leading role of DNA in the conjugates. Following that, SWV was carried out for these two biosensors toward various $\mathrm{Hg}^{2+}$ concentrations $(5,10,20,50,100 \mathrm{nM})$ in PBS containing $0.25 \mathrm{mM}$ $\mathrm{H}_{2} \mathrm{O}_{2}$. Figure 3B displayed the current responses of DNA2-Au@Ag-DNAzyme/Hg ${ }^{2+} / \mathrm{DNA} 1 / \mathrm{Au}$ larger than that of DNA2-Au@Ag/ $/ \mathrm{Hg}^{2+} / \mathrm{DNA} 1 / \mathrm{Au}$. The reason may be the fact that DNAzyme possessed the ability of catalyzing $\mathrm{H}_{2} \mathrm{O}_{2}$ and the current peaks greatly increased due to the participation of catalytic reaction.

\section{Control tests with different experimental conditions}

Taking the practical application of this biosensor into

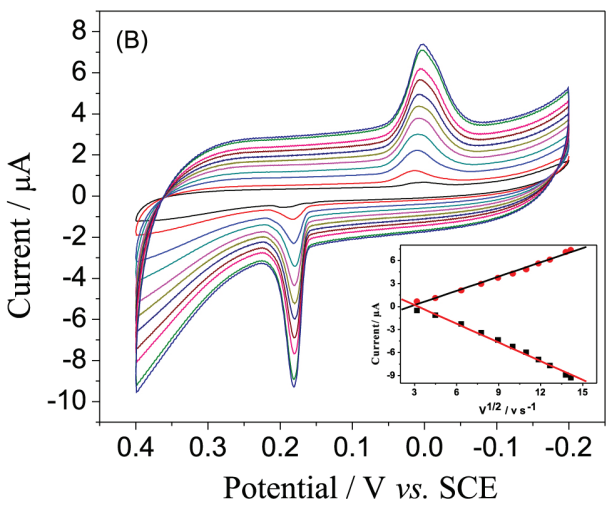

Figure 2. (A) SWV curve of (a) bare Au electrode, (b) DNA2-Au@Ag-DNAzyme/Au electrode and (c) electrode 'b' toward $0.25 \mathrm{mM} \mathrm{H}_{2} \mathrm{O}_{2}$; (B) CV of DNA2-Au@Ag-DNAzyme/Au electrode at different scan rate (inset: linear curve between $\mathrm{I}_{\mathrm{p}}$ and $\mathrm{v}^{1 / 2}$ ). 

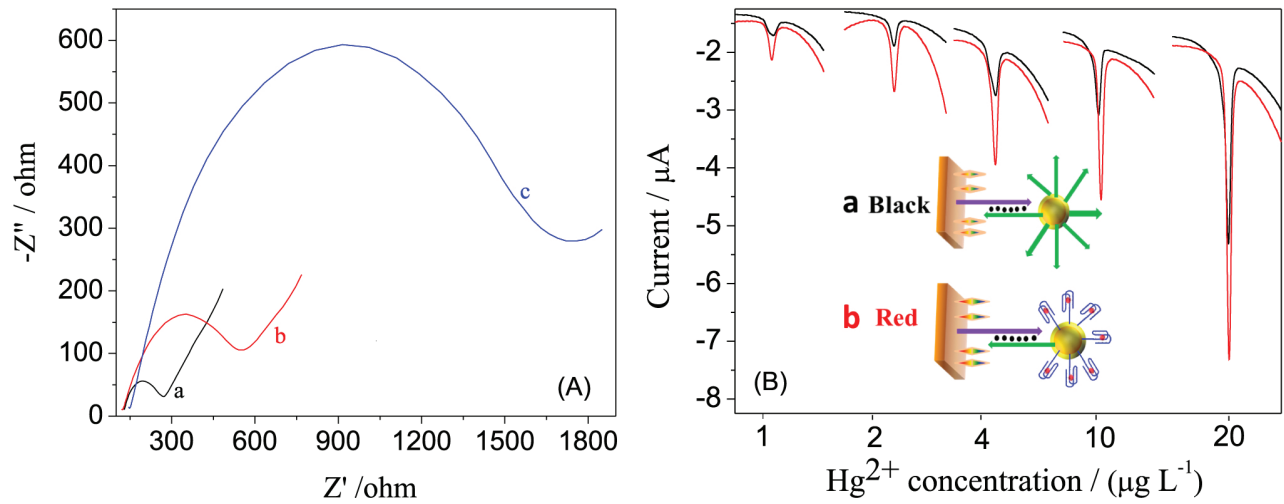

Figure 3. (A) EIS of (a) bare Au electrode, (b) DNA1/Au electrode, and (c) DNA2-Au @ Ag-DNAzyme/ $\mathrm{Hg}^{2+} / \mathrm{DNA} 1 / \mathrm{Au}$ electrode; (B) SWV response of (a) DNA2-Au@ Ag/ $\mathrm{Hg}^{2+} / \mathrm{DNA} 1 / \mathrm{Au}$ electrode and (b) DNA2-Au@Ag-DNAzyme/ $\mathrm{Hg}^{2+} / \mathrm{DNA} 1 / \mathrm{Au}$ electrode toward various $\mathrm{Hg}^{2+}$ concentrations $(5,10$, $20,50,100 \mathrm{nM})$.

consideration in future, all experimental operations were carried out at room temperature $\left(25 \pm 0.5^{\circ} \mathrm{C}\right)$. However, for greatest effectiveness of aptamer biosensor, another experiment conditions such as reaction time and $\mathrm{pH}$ should be further optimized. On the other hand, the combination of $\mathrm{T}-\mathrm{Hg}^{2+}-\mathrm{T}$ was related to incubation time of $\mathrm{Hg}^{2+}$ and DNA2-Au@Ag-DNAzyme conjugate. Figure 4A showed the current response increase with the increasing of incubation time until $35 \mathrm{~min}$ when the current tended to equilibrium. Therefore, $35 \mathrm{~min}$ was chosen as the optimal reaction time throughout this experiment.

Furthermore, the activity of protein could be affected by strong acid or strong base. Figure 4B exhibited the maximum current response at $\mathrm{pH} 6.5$, and the current decreased when $\mathrm{pH}$ was greater or less than 6.5 , which may be attributed to the phenomenon that the structure of DNA was destroyed by strong acid or strong base. Hence, pH 6.5 of PBS was utilized in all electrochemical measurements.

\section{Performance of the DNA biosensor}

Under optimal experimental conditions, the capacity of aptamer electrochemical biosensor for $\mathrm{Hg}^{2+}$ detection was evaluated. The structure of $\mathrm{T}-\mathrm{Hg}^{2+}-\mathrm{T}$ was the function of biosensor for $\mathrm{Hg}^{2+}$ determination, and the current responses increased with the increasing of $\mathrm{Hg}^{2+}$ concentration. Figure 5A displayed the SWV for a series of $\mathrm{Hg}^{2+}$ concentration, which increased gradually and the current intensity was proportional to $\mathrm{Hg}^{2+}$ concentration in the range of 0.002-20 $\mu \mathrm{g} \mathrm{L}^{-1}$ (Figure 5B). The linear equation was $\mathrm{I}=-0.133-0.019 \mathrm{C}_{\mathrm{Hg}}{ }^{2+}\left(\mu \mathrm{g} \mathrm{L}{ }^{-1}\right)\left(\mathrm{R}^{2}=0.999\right.$, $\mathrm{n}=3$ ) with the limit of detection of $0.006 \mu \mathrm{g} \mathrm{L}^{-1}$ $\left(\mathrm{LOD}=3 \sigma_{\text {blank }} / \mathrm{s}\right.$, where $\sigma_{\text {blank }}$ is the relative standard deviation of blank value; $s$ is the slope of line). The maximum contaminant level permitted for mercury in water is $2 \mu \mathrm{g} \mathrm{L}^{-1}$ (USEPA Office of Drinking Water health advisories). Fortunately, the developed biosensor could completely meet the actual needs. For comparison, DNA2-Au@ Ag/ $/ \mathrm{Hg}^{2+} / \mathrm{DNA} 1 / \mathrm{Au}$ was used for detection of $\mathrm{Hg}^{2+}$ and the LOD was $0.1 \mu \mathrm{g} \mathrm{L}^{-1}$. Meanwhile, the LOD of DNA2-Au@Ag-DNAzyme/ $\mathrm{Hg}^{2+} / \mathrm{DNA} 1 / \mathrm{Au}$ was lower than other aptamer sensors such as $\mathrm{Zn}_{3}\left(\mathrm{PO}_{4}\right)_{2} @ \mathrm{DNA}$ $\left(0.014 \mu \mathrm{g} \mathrm{L}^{-1}\right),{ }^{33}$ cationic polymer/DNA $\left(0.03 \mu \mathrm{g} \mathrm{L}^{-1}\right),{ }^{34}$ Y-shaped/hairpin DNA $\left(0.0188 \mu \mathrm{g} \mathrm{L}^{-1}\right),{ }^{35}$ and metal nanoparticle formed by catalysis $\left(0.012 \mu \mathrm{g} \mathrm{L}^{-1}\right){ }^{36}$ The
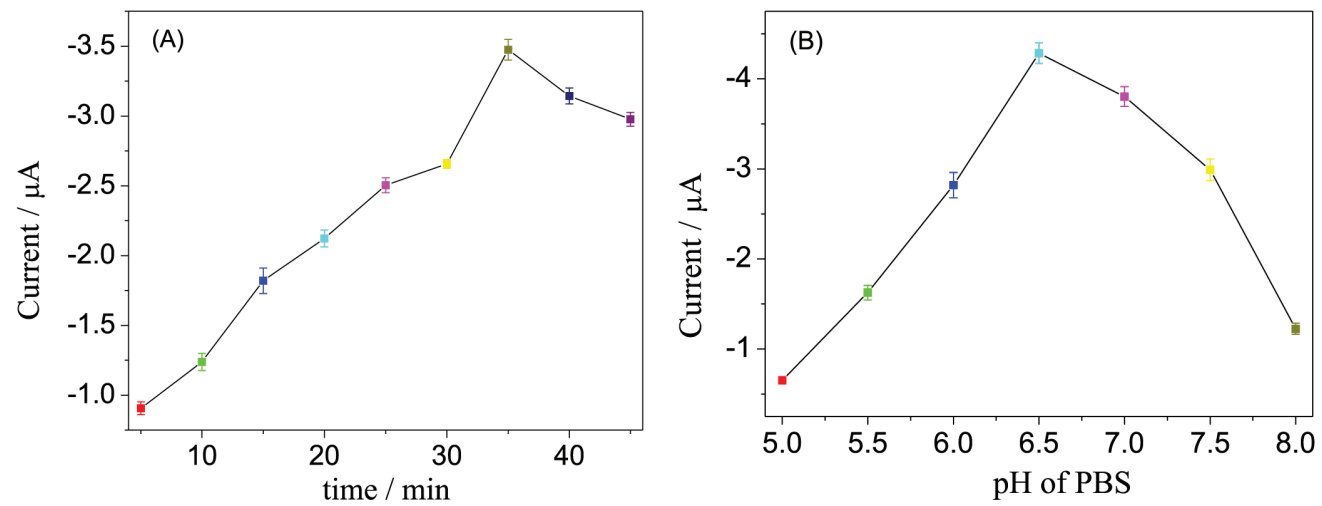

Figure 4. The effect of (A) incubation time, and (B) $\mathrm{pH}$. (Note: each measurement was repeated three times, $\mathrm{n}=3$ ). 
results indicated that the developed biosensor meets outstanding characteristics for $\mathrm{Hg}^{2+}$ determination. There may be some reasons: (i) Au @ Ag core-shell structure not only provided the large specific surface area for the bonding of DNA, but also was favorable to the catalysis of $\mathrm{H}_{2} \mathrm{O}_{2}$; (ii) hemin/G-quadruqlex, as a kind of DNAzyme, could catalyze efficiently $\mathrm{H}_{2} \mathrm{O}_{2}$ and greatly promote electrochemical signals of aptamer biosensor.

Reversibility, stability, repeatability, and selectivity of DNA biosensor

For an excellent biosensor, reversibility, stability, repeatability and selectivity are the important indices. The prepared sensing electrode (DNA2-Au@Ag-DNAzyme/ $\left.\mathrm{Hg}^{2+} / \mathrm{DNA} 1 / \mathrm{Au}\right)$ incubated with L-cysteine solution $(1 \mathrm{mM})$ for $30 \mathrm{~min}$, which turned into initial status (DNA1/Au), because L-cysteine could effectively bond with $\mathrm{Hg}^{2+}$. Then the sensing platform could be re-built according to our previous steps. Figure 6A showed the current change for five regeneration cycles and the SWV signals retained their original signals after five cycles. Meanwhile, five batches of biosensors was constructed and used for detecting $10 \mathrm{nM} \mathrm{Hg}^{2+}$, respectively. The coefficient of variation was $7.8 \%$. Further, the prepared biosensors were stored in PBS (pH 7.0) at $4{ }^{\circ} \mathrm{C}$ for four weeks, and the current still retained 98, 96, 95 and $93 \%$ compared with initial current response after each week.

In addition, selectivity was estimated by testing other metal ions such as $\mathrm{Ca}^{2+}, \mathrm{Mg}^{2+}, \mathrm{Co}^{2+}, \mathrm{Pb}^{2+}, \mathrm{Mn}^{2+}, \mathrm{Fe}^{3+}, \mathrm{Zn}^{2+}$, $\mathrm{Ni}^{2+}$ and $\mathrm{Ag}^{+}$. Figure $6 \mathrm{~B}$ displayed the current responses toward those ions, the larger current signal was obtained only to $\mathrm{Hg}^{2+}$ and other current signals had no significant difference with blank current. Meanwhile, Figure 6C showed the disturbing influence of those heavy metal ions by mixing different ions with $\mathrm{Hg}^{2+}$. The currents were acquired without obvious changes compared with

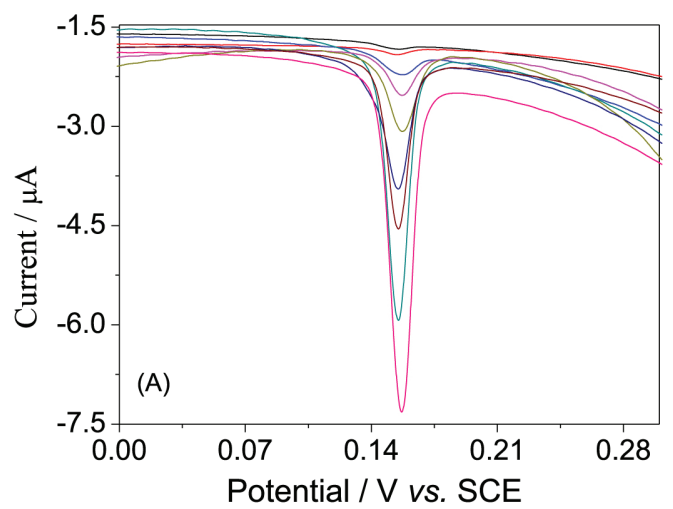

single $\mathrm{Hg}^{2+}$ solution. Those results confirmed that the electrochemical biosensor for $\mathrm{Hg}^{2+}$ detection possesses good reversibility, stability, repeatability and selectivity.

\section{Analysis of real samples}

River, lake and drinking waters were collected, respectively, from Fenhe River, Yingze Lake and laboratory to appraise the ability of this assay for real water samples. Prior to experiment, those water samples were placed for $24 \mathrm{~h}$ at room temperature to subside sediment and centrifuged for $5 \mathrm{~min}$. Then the spiked samples were prepared by adding randomly $\mathrm{Hg}^{2+}$ into those water solutions. Those samples were detected by our developed electrochemical biosensor and referenced colorimetric method. ${ }^{37}$ The results were listed in Table 1 and the $t$ experimental calculation $\left(t_{\text {exp }}\right)$ values were calculated to evaluate correlation of the two method. The $t_{\exp }$ values in all samples were less than $t$ criteria value $\left(\mathrm{t}_{\text {crit }}=4.30 \mu \mathrm{g} \mathrm{L}^{-1}\right)$. Therefore, this electrochemical biosensor prospectively was applied into the field of real water samples detection in future.

\section{Conclusions}

In conclusion, a simple and sensitive electrochemical aptamer biosensor was constructed based on DNAzyme functionalized $\mathrm{Au} @ \mathrm{Ag}$ core-shell nanoparticles as signal tags for $\mathrm{Hg}^{2+}$ detection. The electrochemical signals were enhanced by the following reasons: $(i)$ the specific surface area was enlarged by core-shell nanostructure; (ii) the ability of catalysis was amplified by bimetallic core-shell nanoparticles; (iii) hemin/G-quadruplex as DNAzyme further strengthened the current response by catalyzing $\mathrm{H}_{2} \mathrm{O}_{2}$. The enhanced sensitivity possessed merit of detecting exactly low concentrations of $\mathrm{Hg}^{2+}$, which may offer limitless possibilities for environmental monitoring. More importantly, the limit of detection was far lower than

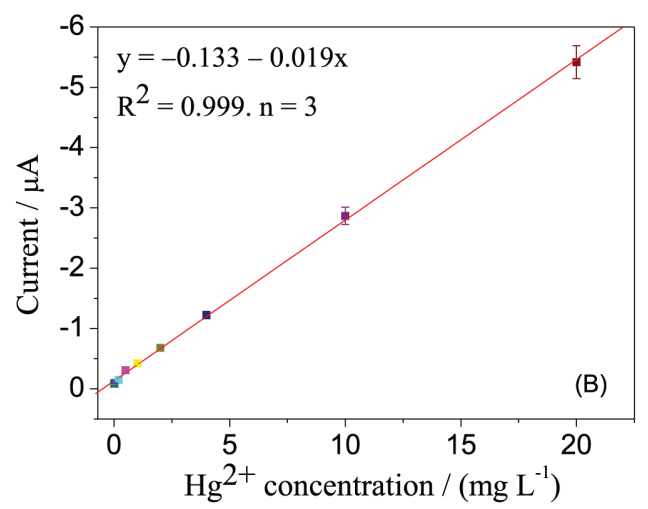

Figure 5. (A) The SWV curves toward different $\mathrm{Hg}^{2+}$ concentration; and (B) calibration curve of the biosensor between current and concentrations of $\mathrm{Hg}^{2+}$ $\left(0,0.02,0.2,0.5,1,2,4,10,20 \mu \mathrm{g} \mathrm{L}{ }^{-1}\right)$. (Note: $\mathrm{n}$ is the number of replications for each concentration). 

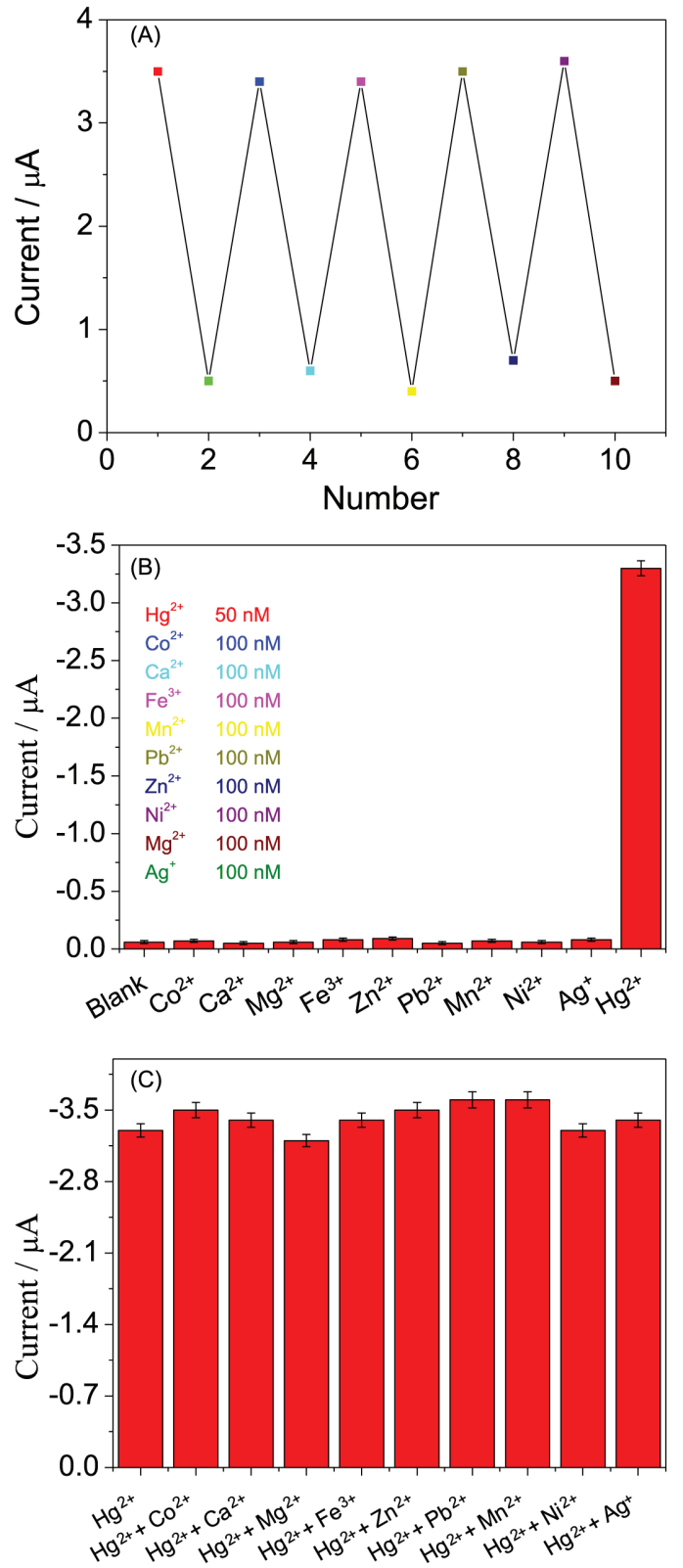

Figure 6. (A) Reversible changes of the SWV peak currents for the biosensor immersed in the solution of $50 \mathrm{nM} \mathrm{Hg}^{2+}$ and $1.0 \mathrm{mM} \mathrm{L}$-cysteine alternately; (B) the specificity and (C) anti-interference quality of the biosensor toward $\mathrm{Co}^{2+}, \mathrm{Ca}^{2+}, \mathrm{Mg}^{2+}, \mathrm{Fe}^{3+}, \mathrm{Zn}^{2+}, \mathrm{Mn}^{2+}, \mathrm{Pb}^{2+}, \mathrm{Ni}^{2+}, \mathrm{Ag}^{+}$.

permitted concentration of $\mathrm{Hg}^{2+}$ in water. The performance of developed biosensor was outstanding compared with other $\mathrm{Hg}^{2+}$ biosensors. Moreover, the proposed biosensors could analyse other targets determination by simply replacing responsive aptamer, which could expand its application in future.

\section{Acknowledgments}

The National Natural Science Foundation of China (Grant No. 21605111), Natural Science Foundation of Shanxi
Table 1. Comparison of the assay results for real samples by using the developed electrochemical biosensor $\left(\mathrm{C}_{\text {(biosensor })}\right.$, mean \pm standard deviation, $\mathrm{n}=3)$ and the referenced colorimetric method $\left(\mathrm{C}_{\text {(colorimetric) }}\right.$, mean \pm standard deviation, $\mathrm{n}=3$ )

\begin{tabular}{lccc}
\hline Sample & $\begin{array}{c}\mathrm{C}_{(\text {colorimetric) }} / \\
\left(\mu \mathrm{g} \mathrm{L}^{-1}\right)\end{array}$ & $\begin{array}{c}\mathrm{C}_{\text {(biosensor) }} / \\
\left(\mu \mathrm{g} \mathrm{L}^{-1}\right)\end{array}$ & $\left.\mathrm{t}_{\text {exp }} /(\mu \mathrm{g} \mathrm{L})^{-1}\right)$ \\
\hline \multirow{2}{*}{ Drinking water } & $5.12 \pm 1.09$ & $6.12 \pm 1.16$ & -1.08 \\
& $6.47 \pm 1.08$ & $6.64 \pm 0.08$ & -0.27 \\
\hline \multirow{2}{*}{ Lake } & $10.32 \pm 0.25$ & $10.26 \pm 1.08$ & 0.09 \\
& $4.76 \pm 0.22$ & $4.13 \pm 1.36$ & 0.79 \\
& - & $1.08 \pm 0.05$ & - \\
\hline \multirow{2}{*}{ River } & $15.23 \pm 3.02$ & $20.12 \pm 0.17$ & -2.77 \\
& $16.43 \pm 2.14$ & $16.08 \pm 3.19$ & 0.15 \\
& $9.19 \pm 0.78$ & $9.7 \pm 1.68$ & -0.48 \\
\hline
\end{tabular}

$\mathrm{t}_{\text {exp }}: \mathrm{t}$ experimental calculation values.

Province (No. 201601D021037) and Youth Foundation of Taiyuan University of Technology (2015QN033) are gratefully acknowledged.

\section{References}

1. Mekonnen, M.; Hoekstra, A.; Environ. Sci. Technol. 2015, 49, 12860 .

2. Lyubimova, T.; Lepikhin, A.; Parshakova, Y.; Tiunov, A.; J. Hydrol. 2016, 534, 579.

3. Zhou, J.; Wang, Z.; Sun, T.; Zhang, H.; Zhang, X.; Environ. Pollut. 2016, 212, 188.

4. Vogel, C.; Krüger, O.; Herzel, H.; Amidani, L.; Adam, C.; J. Hazard. Mater. 2016, 313, 179.

5. Cui, X.; Zhu, L.; Wu, J.; Hou, Y.; Wang, P.; Wang, Z.; Yang, M.; Biosens. Bioelectron. 2015, 63, 506.

6. Xu, L.; Yin, H.; Ma, W.; Kuang, H.; Wang, L.; Xu, C.; Biosens. Bioelectron. 2015, 67, 472.

7. Li, W.; Chen, B.; Zhang, H.; Sun, Y.; Wang, J.; Zhang, J.; Fu, Y.; Biosens. Bioelectron. 2015, 66, 251.

8. Wang, H.; Chen, B.; Zhu, S.; Yu, X.; He, M.; Hu, B.; Anal. Chem. 2016, 88, 796 .

9. Zahida, A.; Lashinb, A.; Ranad, U.; Al-Arifie, N.; Ullaha, I.; Dionysiouf, D.; Qureshia, R.; Waseema, A.; Kraatzg, H.; Shah, A.; Electrochim. Acta 2016, 190, 1007.

10. Li, F.; Zhang, H.; Wang, Z.; Li, X.; Li, X.; Le, X.; J. Am. Chem. Soc. 2013, 135, 2443.

11. Tan, C.; Yu, P.; Hu, Y.; Chen, J.; Huang, Y.; Cai, Y.; Luo, Z.; Li, B.; Lu, Q.; Wang, L.; Liu, Z.; Zhang, H.; J. Am. Chem. Soc. 2015, 137, 10430.

12. Abi, A.; Ferapontova, E.; J. Am. Chem. Soc. 2012, 134, 14499.

13. Zhu, Y.; Hu, X.; Shi, S.; Gao, R.; Huang, H.; Zhu, Y.; Lv, X.; Yao, T.; Biosens. Bioelectron. 2016, 79, 205. 
14. Zhou, G.; Chang, J.; Pu, H.; Shi, K.; Mao, S.; Sui, X.; Ren, R.; Cui, S.; Chen, J.; ACS Sens. 2016, 1, 295.

15. Zhang, L.; Wong, J.; Li, X.; Li, Y.; Yu, H.; Anal. Chem. 2015, $87,5062$.

16. Cui, L.; Peng, R.; Fu, T.; Zhang, X.; Wu, C.; Chen, H.; Liang, H.; Yang, C.; Tan, W.; Anal. Chem. 2016, 88, 1850.

17. Zhou, Y.; Tang, L.; Zeng, G.; Zhang, C.; Zhang, Y.; Xie, X.; Sens. Actuators, B 2016, 223, 280.

18. Cui, L.; Wu, J.; Li, J.; Ju, H.; Anal. Chem. 2015, 87, 10635.

19. Li, J.; Lu, L.; Kang, T.; Cheng, S.; Biosens. Bioelectron. 2016, $77,740$.

20. Qiu, Z.; Tang, D.; Shu, J.; Chen, G.; Tang, D.; Biosens. Bioelectron. 2016, 75, 108.

21. Wei, T.; Dong, T.; Wang, Z.; Bao, J.; Tu, W.; Dai, Z.; J. Am. Chem. Soc. 2015, 137, 8880.

22. Abo-Hamad, A.; AlSaadi, M.; Hayyan, M.; Juneidi, I.; Hashim, M.; Electrochim. Acta 2016, 193, 321.

23. Liu, X.; Cheng, Z.; Fan, H.; Ai, S.; Han, R.; Electrochim. Acta 2011, 56, 6266.

24. Primo, E.; Gutierrez, F.; Rubianes, M.; Rivas, G.; Electrochim. Acta 2015, 182, 391.

25. Tang, S.; Lu, W.; Gu, F.; Tong, P.; Yan, Z.; Zhang, L.; Electrochim. Acta 2014, 134, 1.

26. Arslan, E.; Çakır, S.; J. Electroanal. Chem. 2016, 760, 32.
27. Zhou, Q.; Lin, Y.; Lin, Y.; Wei, Q.; Chen, G.; Tang, D.; Biosens. Bioelectron. 2016, 78, 236.

28. Yuan, F.; Zhao, H.; Zang, H.; Ye, F.; Quan, X.; ACS Appl. Mater. Interfaces 2016, 8, 9855.

29. Wang, N.; Han, Y.; Xu, Y.; Gao, C.; Cao, X.; Anal. Chem. 2015, $87,457$.

30. Wang, Z.; Zhao, J.; Bao, J.; Dai, Z.; ACS Appl. Mater. Interfaces 2016, 8,827 .

31. Zhang, B.; Ding, C.; Biosens. Bioelectron. 2016, 82, 112.

32. Wei, T.; Dong, T.; Wang, Z.; Bao, J.; Tu, W.; Dai, Z.; J. Am. Chem. Soc. 2015, 137, 8880.

33. He, L.; Zhang, S.; Wang, M.; Peng, D.; Yan, F.; Zhang, Z.; Zhou, L.; Sens. Actuators, B 2016, 228, 500.

34. Zhu, Y.; Cai, Y.; Zhu, Y.; Zheng, L.; Ding, J.; Quan, Y.; Wang, L.; Qi, B.; Biosens. Bioelectron. 2015, 69, 174.

35. Jia, J.; Chen, H.; Feng, J.; Lei, J.; Luo, H.; Li, N.; Anal. Chim. Acta 2016, 908, 95.

36. Tang, S.; Tong, P.; Lu, W.; Chen, J.; Yan, Z.; Zhang, L.; Biosens. Bioelectron. 2014, 59, 1.

37. Borthakur, P.; Darabdhara, G.; Das, M.; Boukherroub, R.; Szunerits, S.; Sens. Actuators, B 2017, 244, 684.

Submitted: January 14, 2017

Published online: July 11, 2017 